\title{
Impacts of supplementary drainage on the water balance of a poorly drained agricultural field
}

\section{Haggblom, Olle}

2019-08-20

Haggblom , O, Salo , H , Turunen , M , Nurminen , J , Alakukku , L, Myllys , M \& Koivusalo , H 2019, ' Impacts of supplementary drainage on the water balance of a poorly drained agricultural field ' , Agricultural Water Management , vol. 223 , 105568 . https://doi.org/10.1016/j.agwat.2019.03.039

http://hdl.handle.net/10138/334425

https://doi.org/10.1016/j.agwat.2019.03.039

cc_by_nc_nd

acceptedVersion

Downloaded from Helda, University of Helsinki institutional repository.

This is an electronic reprint of the original article.

This reprint may differ from the original in pagination and typographic detail.

Please cite the original version. 


\section{Impacts of supplementary drainage on the water balance of a poorly drained agricultural field}

Häggblom Olle ${ }^{\mathrm{a}, \mathrm{c} *}$, Salo Heidi ${ }^{\mathrm{a}}$, Turunen Mika ${ }^{\mathrm{b}}$, Nurminen Jyrki ${ }^{\mathrm{c}}$, Alakukku Laura ${ }^{\mathrm{d}}$, Myllys Merja ${ }^{\mathrm{b}}$, Koivusalo Harri ${ }^{\mathrm{a}}$

*Corresponding author information: tel. +358 405878014, email: olle.haggblom@ @alaojayhdistys.fi aAalto University, School of Engineering, Department of Built Environment, P.O. Box 15200, FI00076 AALTO, Tietotie 1 E, 02150 Espoo, Finland.

${ }^{b}$ Natural Resources Institute Finland.

${ }^{c}$ Finnish Field Drainage Association, Simonkatu 12 A 11, FI-00100 Helsinki.

${ }^{\mathrm{d} U n i v e r s i t y ~ o f ~ H e l s i n k i, ~ D e p a r t m e n t ~ o f ~ A g r i c u l t u r a l ~ S c i e n c e s, ~ A g r o t e c h n o l o g y ~ R e s e a r c h ~ G r o u p . ~}$ 


\begin{abstract}
In northern clay soils, field drainage is needed to ensure suitable moisture conditions for crop growth and farming operations. Supplementary drainage installations improve the efficiency of old drainage systems, but the hydrological impacts of the drainage procedures are not comprehensively understood or quantified. The objective was to simulate the hydrological behavior of a clay field section and to quantify the effects of a supplementary drainage on the water balance of the field section. The study site, in southern Finland, was originally subsurface drained in 1952 with $32 \mathrm{~m}$ drain spacing. Supplementary drainage was installed in 2014, decreasing the drain spacing to $10.7 \mathrm{~m}$. Simulations were carried out with a dual-permeability hydrological model and two model parametrizations describing the field hydrology (1) before and (2) after the supplementary drainage installation. The parameterizations were used for simulations of a nine-year period to quantify the hydrological impacts of the supplementary drainage. For the periods without snow on the ground, the modified Nash-Sutcliffe efficiency for daily drain discharge and topsoil layer runoff values ranged from 0.43 to 0.53 and from 0.44 to 0.53 , respectively. During the original drainage setup scenario, the average annual drain discharge was lower (7.8\% of precipitation) than topsoil layer runoff and groundwater outflow (10.3\% and $26.4 \%$, respectively). For the supplementary drainage scenario, most of the water outflow was through drain discharge and groundwater outflow (20.4\% and $21.9 \%$, respectively). The supplementary drainage installation increased the average annual drain discharge by a factor of 2.6, while the annual average topsoil layer runoff and groundwater outflow decreased by $75 \%$ and $18 \%$, respectively. The supplementary drainage setup was found to expedite the drying of the field section in spring by 8 days on average compared to the original drainage setup.
\end{abstract}

\title{
Keywords
}

Clayey field; Macropores; Groundwater outflow; FLUSH model 


\section{Introduction}

In Finland and other regions of the boreal climate zone, the annual precipitation exceeds the annual evapotranspiration. The main part of evapotranspiration takes place during May to September, while the dormant seasons are characterized by low evapotranspiration (e.g. Kersalo and Pirinen, 2009; Jin and Sands, 2006) during autumn rains, winter snow accumulation, and spring snow melt (typically occurring during the months of March and April) (Kersalo and Pirinen, 2009). These hydroclimatic conditions create a need for field drainage to ensure suitable moisture conditions during the field cultivation practices. The need for drainage is most prominent in spring after the snow melt period before the growing season, and in autumn when evapotranspiration decreases (e.g. Turtola and Paajanen, 1995). The need for drainage in springtime may be further amplified due to climate change, which is projected to increase precipitation during winter and spring in Finland (Ruosteenoja et al., 2016). Efficiently functioning drainage systems have been found to improve the structure and workability of the soil (e.g. Alakukku et al., 2003) and increase its load-bearing capacity (Kandel et al., 2013), thus permitting heavy agricultural traffic without risk of soil compaction and prolonging the period of intensive agriculture.

In Finland, field drainage is mainly (almost $60 \%$ of the field area, 1.3 million ha) implemented by subsurface drains (Peltomaa, 2016). Almost $40 \%$ of the fields in Finland are located on clayey soils (Luke, 2018) that have a recommended drain spacing and depth of 10-14 $\mathrm{m}$ and $1 \mathrm{~m}$, respectively (Peltomaa, 2016). Most of the drainage systems were installed during the latter half of the $20^{\text {th }}$ century (Saavalainen, 2001), and Puustinen (1994) noted a growing need for supplementary or renewed drainage installation, which still exists today, due to (1) degradation of the old systems, (2) new drainage guidelines, and (3) increased weight of agricultural machinery (Salaojayhdistys, 2015). The clay soils are characterized by a low hydraulic conductivity and a dominating preferential flow in macropores, such as plant root channels and earth-worm burrows (e.g. Gärdenäs et al., 2006; Turtola et al., 2007; Klaus and Zehe, 2010). The preferential macropore flow has been found to play a decisive role in the hydrology of agricultural soils. Both Frey et al. (2016) and Warsta et al. (2013a) found that over $98 \%$ of subsurface drain discharge originated from the macropore system. Jarvis (2007) concluded that significant preferential flow is activated with a pore size of $0.3 \mathrm{~mm}$ (cylindrical diameter equivalent). Pores larger than or equal to this size are usually defined as macropores (e.g. Aura, 1995).

The dominant water balance components of a field include precipitation, evapotranspiration, topsoil layer runoff, drainage discharge, groundwater outflow, and change in soil water storage. Drain discharge and surface/topsoil layer runoff have been extensively measured and analyzed in previous 
studies (e.g. Vakkilainen et al., 2010; Äijö et al., 2014), and the effects of supplementary drainage installation on these components in northern conditions are relatively well known (e.g. Seuna and Kauppi, 1981; Turtola and Paajanen, 1995). There is still need for a holistic examination of the effects of a supplementary drainage installation on the complete water balance, including the groundwater outflow component, which can form a considerable part of the water balance (Rozemeijer and Broers, 2007; Turunen et al., 2013, 2015a; McKnight et al., 2015) and has often been ignored in previous studies (Weiler and McDonell, 2007) especially as a pathway for nutrient leaching (Nollet and Rathore, 2012). There is also evidence of high-conductivity soil layers in till and clay soils, which could cause high lateral groundwater outflow (Yli-Halla et al., 2009; Kessler et al., 2012). The groundwater outflow, however, has proven difficult to quantify and measure. Rozemeijer et al. (2010) are among the few who have succeeded in quantifying the groundwater outflow from an intensely drained agricultural plot through direct measurement. Another approach is to use hydrological modeling to quantify the groundwater outflow component (e.g. Turunen et al., 2013; 2015a).

The hydrology of clay fields in Nordic conditions has earlier been studied through direct measurement campaigns (e.g. Seuna and Kauppi, 1981; Turtola and Paajanen, 1995; Vakkilainen et al., 2010; Äijö et al., 2014) and through model applications where the field is described as a one-dimensional (1D) soil column (e.g. Hintikka et al., 2008), as a two-dimensional (2D) transect (e.g. Mante et al., 2018; Gärdenäs et al., 2006; Koivusalo et al., 1999), or as a three-dimensional (3D) description of the field site (Turunen et al., 2013, 2015a, 2015b; Warsta et al., 2013a). Because 1D model applications are computationally light, 2D or 3D models are needed to describe sloping or undulating fields (e.g. Gärdenäs et al., 2006; Hintikka et al., 2008) and heterogeneous soil properties (Filipovic et al., 2015; Salo et al., 2017). While 2D and 3D models provide the most advanced computational description, they have not been used to quantify the hydrological effects of improved or supplementary drainage on a subsurface drained clay field.

This study aimed to quantify the hydrological impacts of a supplementary drainage installation on the water balance of a clayey field section. The approach was based on combining a 2D model application with 10 years of intensive hydrological measurements (Äijö et al. 2014, 2017). This provided means to estimate the impacts on all dominating water balance components. The spatially distributed FLUSH model (Warsta et al., 2013a) was selected for this study, as it has been tested for simulating water flow in subsurface drained clay soils (e.g. Turunen et al., 2013; Koivusalo et al., 2017) and includes a description for simulating preferential flow. A 2D model approach was necessary to simulate the effect of a steep slope at the field section boundary. FLUSH also supported 
a detailed parametrization of old and new drain sections in the computational domain. The specific objectives of this article were to shed more light on the following questions:

1. How does a supplementary drainage installation affect the water balance of a clayey field section in high-latitude conditions, and what role does the groundwater outflow (i.e. lateral subsurface outflow from the field to the main ditch at the border of the field) play as a part of the water balance?

2. Can a process-based hydrological model holistically describe the impacts of the supplementary drainage procedures on the field hydrology, and how does the drainage installation affect the groundwater depth in spring after the snow melt period?

\section{Materials}

\subsection{Site description}

The study site is a cultivated clayey field located in Jokioinen, Southwestern Finland (Fig. 1a), and managed by Natural Resources Institute Finland. The studied field section (3.4 ha) has a mean slope of $0.5 \%$ towards the Raiskionoja creek in the northeast. Closer to the creek (outside the cultivated area), the slope increases to $12 \%$. The field section has been monitored since June 2007, during which the cultivated crops were spring sown oats (Avena sativa) and barley (Hordeum vulgare) (Vakkilainen et al., 2010; Äijö et al., 2014; 2017). The field section has typically been tilled with a light s-tine harrow (tillage depth $0.05-0.06 \mathrm{~m}$ ) in spring before sowing and with a tine cultivator (maximum tillage depth $0.2 \mathrm{~m}$ ) in autumn after harvest.
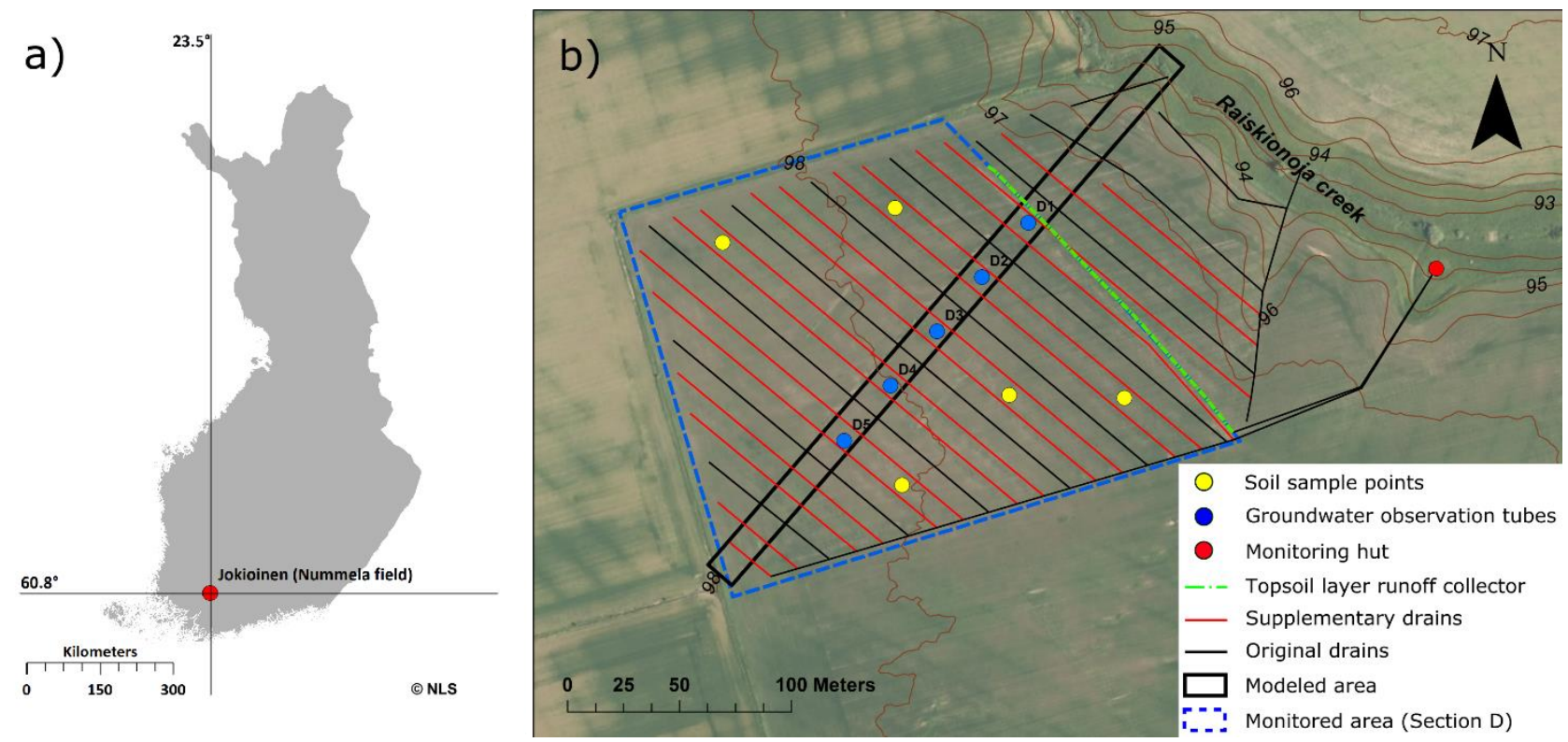

Figure 1. The location of Jokioinen (a), and a layout of the field and the measurement setup (b). 
The original tile drains were installed at the field section in 1952 with a drain spacing of $32 \mathrm{~m}$ and at an average depth of $1 \mathrm{~m}$. The drain spacing exceeded the recommendations of Finnish drainage guidelines (Peltomaa, 2016) and thus, represented a poorly drained field section, where waterlogging occurred occasionally. Small amounts of gravel were presumably used as envelope material around the tiles and tile segment joints. In May 2014 two supplementary drains were installed between each existing drain at an average depth of $1 \mathrm{~m}$, resulting in a drain spacing of $10.7 \mathrm{~m}$. The plastic supplementary drains were installed with the trench excavation method and approximately $0.5 \mathrm{~m}$ of gravel was used above the drains as trench backfill and envelope material. Additionally, vertical gravel inlets reaching the bottom of the topsoil layer $(0.2 \mathrm{~m}$ below the soil surface $)$ were installed every $10 \mathrm{~m}$ along the supplementary drain lines. Both the original drains and the supplementary drains had an inner diameter of $0.05 \mathrm{~m}$. A more detailed site description can be found in Vakkilainen et al. (2010), Äijö et al. (2017) and Turunen et al. (2013).

\subsection{Hydrometeorological data}

Since June 2007, precipitation, drain discharge, and topsoil layer runoff have been monitored continuously (at $15 \mathrm{~min}$. intervals). The hydrological data used in this study spanned a 10-year period until May 2017. Precipitation was measured with a Rainew 111 tipping bucket gauge (RainWise, Inc., Bar Harbor, ME, USA). The drain discharge and topsoil layer runoff were measured with Datawater WS vertical helix water meters (Maddalena, Povoletto, Italy). The precipitation correction factor was 1.05 for rain and 1.3 for snowfall, following Førland et al. (1996). The area of the monitored subsurface drainage was $3.4 \mathrm{ha}$, and the topsoil layer runoff was collected from an area of 2.7 ha. The topsoil layer runoff collector (Fig. 1b) was installed at a depth of $0.4 \mathrm{~m}$ with gravel backfilling to the soil surface. Weekly ground water depth observations were taken at the midpoint between the drain lines at locations D1-D5 (Fig. 1b) during June 2007-May 2014, and at locations D2-D5 (Fig. 1b) during June 2014-May 2017. The depth to the water table was observed with a manual tape measure with an accuracy of $0.01 \mathrm{~m}$. The observation tubes were closed-bottom perforated plastic pipes $(\varnothing 0.05 \mathrm{~m})$ that reached a depth of $1.6 \mathrm{~m}$ (范ö et al., 2017).

Meteorological data for the field site, including hourly precipitation, air temperature, relative humidity, wind speed, and global radiation, was available from the Finnish Meteorological Institute (FMI) weather station in Jokioinen (located $7 \mathrm{~km}$ southeast of the site). Missing data was replaced with records from Helsinki-Vantaa Airport (located $100 \mathrm{~km}$ southeast of the site). The potential evapotranspiration (PET) was calculated with the same approach used by Turunen et al. (2015a), following Allen et al. (1998). 
The hydrometeorological data was aggregated into hourly values when used in the modeling.

\subsection{Soil properties}

Soil physical properties for the field section were analyzed from five undisturbed soil samples taken in autumn 2006. The samples (diameter $0.15 \mathrm{~m}$ and length $0.6 \mathrm{~m}$ ) were taken in PVC pipes with a tractor driven auger at the midpoint between the original drain lines (Fig. 1b). Each soil sample was divided into three layers, representing the topsoil layer $(0-0.2 \mathrm{~m})$, the plow pan $(0.2-0.4 \mathrm{~m})$ and the subsoil (0.4-0.6 m). The total porosity, the water retention curves (WRC), and the macroporosity were measured with the desorption method (Danielson and Sutherland, 1986) and the osmotic method (Williams and Shaykewich, 1969). The mean saturated hydraulic conductivity $\left(K_{s a t}\right)$ of soil layers was $0.04 \mathrm{~m} \mathrm{~h}^{-1}$ for the topsoil layer and $0.00001 \mathrm{~m} \mathrm{~h}^{-1}$ for the deeper layers and was measured according to Youngs (1991). A more detailed description of the soil properties is found in Vakkilainen et al. (2010).

Soil particle-size analysis, in the study of Vakkilainen et al. (2010), was carried out mechanically with a method of Elonen (1971) for a different set of (disturbed) soil samples taken from three layers at the depths of $0.0-0.35 \mathrm{~m}, 0.35-0.65 \mathrm{~m}$, and $0.65-1.0 \mathrm{~m}$ from the soil surface. The soil was classified as Vertic Luvic Stagnasol (IUSS Working Group WRB, 2015). The topsoil layer had an average clay content of $67 \%$ and the deeper layers had a clay content of $72-86 \%$, increasing with depth. The average amount of organic material in the topsoil layer was $6.5 \%$. The amount of organic material decreased with depth to $1.1 \%(0.35-0.6 \mathrm{~m})$ and 0.5\% (0.65-1.0 m) (Vakkilainen et al., 2010). 


\section{Methods}

\subsection{FLUSH model}

FLUSH is an open source 3D hydrological model developed to simulate water flow and erosion (Warsta et al., 2013a, b) in clayey fields with subsurface drainage. The process-based model simulates subsurface water flow with a dual-permeability approach (e.g. Šimůnek and van Genuhten, 2008), taking into account preferential flow typical for structured soils such as clay (Warsta et al., 2013a). The model has been further developed to simulate open ditch processes (Haahti et al., 2016), and solute transport (Salo et al., 2015).

The conceptual water flow dynamics in the model are driven by precipitation entering the soil surface domain, where it is initially stored in the soil surface depression storage. If the precipitation is in the form of snow, it will lead to snow accumulation. Water flow can occur at the surface domain when the soil surface depression storage capacity is exceeded, and the flow is driven by gravitational and hydraulic pressure head. Water is lost from the soil surface by surface runoff to ditches, or by infiltration into the soil matrix or macropore system in the subsurface domain. Infiltration into the subsurface domain is computed according to Darcy's law and is limited when the maximum infiltration rate is reached or the subsurface domain is completely saturated. In the subsurface domain, water flows in the soil matrix and macropores systems, but water exchange can also occur between the two pore systems (e.g. Šimůnek and van Genuchten, 2008). Water from the subsurface domain is lost by evapotranspiration, topsoil layer runoff to open ditches, discharge to subsurface drains, or groundwater outflow.

The model divides the simulated area into a 2D overland flow domain and a 3D subsurface flow domain. The water flow in the overland domain is simulated with the diffuse wave approximation of the Saint Venant equations. The Richards equation (Richards, 1931) is used for simulating the water flow in both pore systems in the subsurface domain (Warsta et al., 2013a). The numerical solution of the Richards equation uses the implicit finite volume method to discretize the spatial components and backward difference method for the temporal terms (see details in Warsta et al., 2013a). The model presents the output with an hourly time step. The soil moisture content and the unsaturated hydraulic conductivity are calculated with the van Genuchten (1980) WRC. Wintertime processes (snow accumulation and melt) were computed with an energy and snowpack submodel (Koivusalo et al., 2001), which was originally coupled with the FLUSH model by Warsta et al. (2012).

Water flow into drains and ditches from both pore systems are calculated with the Darcy approach using Eq. 1: 


$$
q=K_{s a t} A_{s} \frac{H_{c}-H_{s}}{\lambda}
$$

where $q\left[\mathrm{~m}^{3} \mathrm{~h}^{-1}\right]$ is the volumetric flux into the sink (drain or ditch), $K_{\text {sat }}\left[\mathrm{m} \mathrm{h}^{-1}\right]$ is the saturated hydraulic conductivity of the cell, $A_{s}\left[\mathrm{~m}^{2}\right]$ is the surface area of the sink, $H_{c}[\mathrm{~m}]$ is the hydraulic head in the cell, $H_{S}$ is the hydraulic head in the sink, and $\lambda$ is an entrance resistance parameter. (Warsta et al., 2013a; Turunen et al., 2013).

In this study, the original version of the model (Warsta et al., 2013a) was modified to use a prebuilt computational grid. The grid was prebuilt and read into the model from a vtk file. The solution enabled the use of structured grids with varying cell sizes, while the original automatic grid generation algorithm of Warsta et al. (2013a) created grids with uniform cell size. The computational grid with varying cell size enabled a higher resolution in the vicinity of the drains, while the resolution is lower between the drains, thus saving computation time.

\subsection{The computational domain}

The model application and parametrization were based on previous model applications on the field site (Häggblom, 2017; Turunen et al., 2013; 2015b). The computational grid was a 2D transect of the field section positioned parallel to the slope and perpendicular to the subsurface drains (Fig. 1b). The length of the computational domain was $300 \mathrm{~m}$ (x-direction), width $4 \mathrm{~m}$ (y-direction), and depth $6 \mathrm{~m}$ (z-direction) (Fig. 2). The cell size of the grid in the y-direction was $4 \mathrm{~m}$. In the $\mathrm{x}$-direction, the cell size varied from 0.15 to $3.0 \mathrm{~m}$, being largest midway between the drain locations and gradually decreasing to $0.15 \mathrm{~m}$ at the drain location (Fig. 2). The $0.15 \mathrm{~m}$ cell size was used for enabling representation of the trench above the subsurface drains (Salo et al., 2017). The larger cell sizes were used between the drains in the x-direction, as the soil properties were assumed to be homogeneous elsewhere than at the drain locations. In the vertical direction (z-direction), the computational area was divided into 25 layers, where the cell depth varied between 0.02 and $0.5 \mathrm{~m}$, increasing from the surface to the bottom (Fig. 2). The bottom and horizontal boundaries of the computational domain were set to have no flow boundary conditions. A head- and state-dependent boundary was set on the uppermost cells of the subsurface domain. Fig. 2 visualizes the grid structure in a $21.4 \mathrm{~m}$ section of the computational grid including one original drain and one supplementary drain. 
Three open ditches were placed in the computational area: (1) a $0.4 \mathrm{~m}$ deep ditch at the southwest end of the computational grid, (2) the $0.4 \mathrm{~m}$ deep topsoil layer runoff collector, and (3) the $1.0 \mathrm{~m}$ deep Raiskionoja creek at the northeast end of the grid (see Fig. 1b). The seepage from the subsurface domain to the open ditch at the Raiskionoja creek (3) was defined as lateral groundwater outflow. The subsurface drain (original and supplementary) locations in the model were set according to their locations in the field (Fig. 1b).

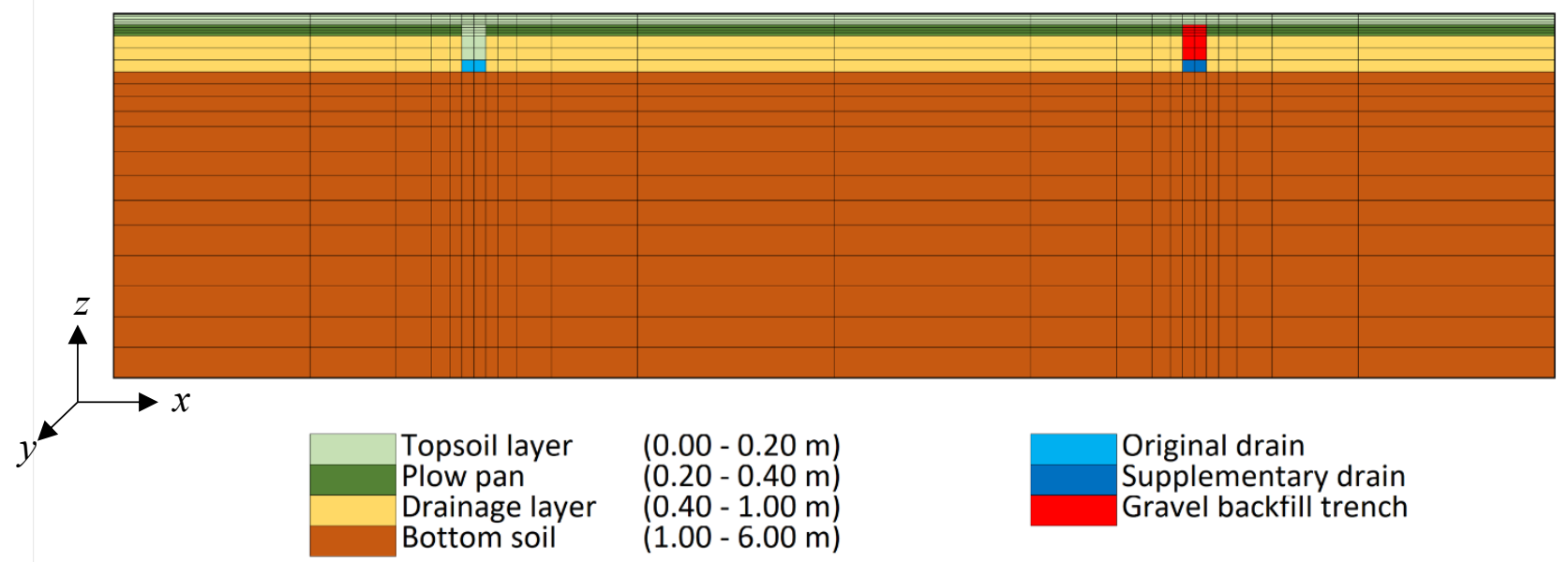

Figure 2. A $21.4 \mathrm{~m}$ long section of the computational grid from the supplementary drainage setup. The figure shows one original drain (left) and one supplementary drain (right).

\subsection{Model parametrization}

Two model parametrizations (drainage scenarios) were created to describe the two drainage setups. The first parametrization described the original drainage ( $32 \mathrm{~m}$ drain spacing), and the second parametrization the field with supplementary drainage (10.7 m drain spacing). The only differences between the two parametrizations were the supplementary drains with gravel trenches (Fig. 2). The modeled trenches of the supplementary drains were filled with gravel up to the topsoil layer $(0.2 \mathrm{~m}$ from the soil surface). Gravel was not used above the modeled original drains; instead, the soil had the hydraulic properties of the topsoil layer (i.e. a higher amount of macropores) and thus a higher hydraulic conductivity, following the findings of Messing and Wesström (2006) and Alakukku et al. (2010). The saturated hydraulic conductivity in the macropores was calculated by multiplying the macroporosity $(\omega)$ by the conductivity multiplier $\left(K_{s a t, M U L T}\right)$ (Warsta et al., 2013a).

The calibration and validation periods for the original drainage were the three years following June 2008 and the three years following June 2011, respectively (Fig. 3). The calibration and validation periods for the supplementary drainage were one year following June 2014 and two years following June 2015, respectively. The period of June 2007-May 2008 was used as a warm-up period for the model to mitigate the effect of the initial values. The parametrization was partly based on previous 
studies (see Table 1) and partly on manual calibration. The calibrated parameters included soil parameters listed in Table 1 as well as drainage parameters ( $\lambda$ and $H_{s}$ in Eq. 1). The total hydraulic conductivity $\left(K_{\text {matrix }}+K_{\text {macropore }}\right)$ of the bottom soil layer $(1.00-6.00 \mathrm{~m})$ was calibrated through the macroporosity $(\omega)$ and the saturated water content of the soil matrix $\left(\theta_{\text {sat }}\right)$ below the drain depth (bottom soil layer).

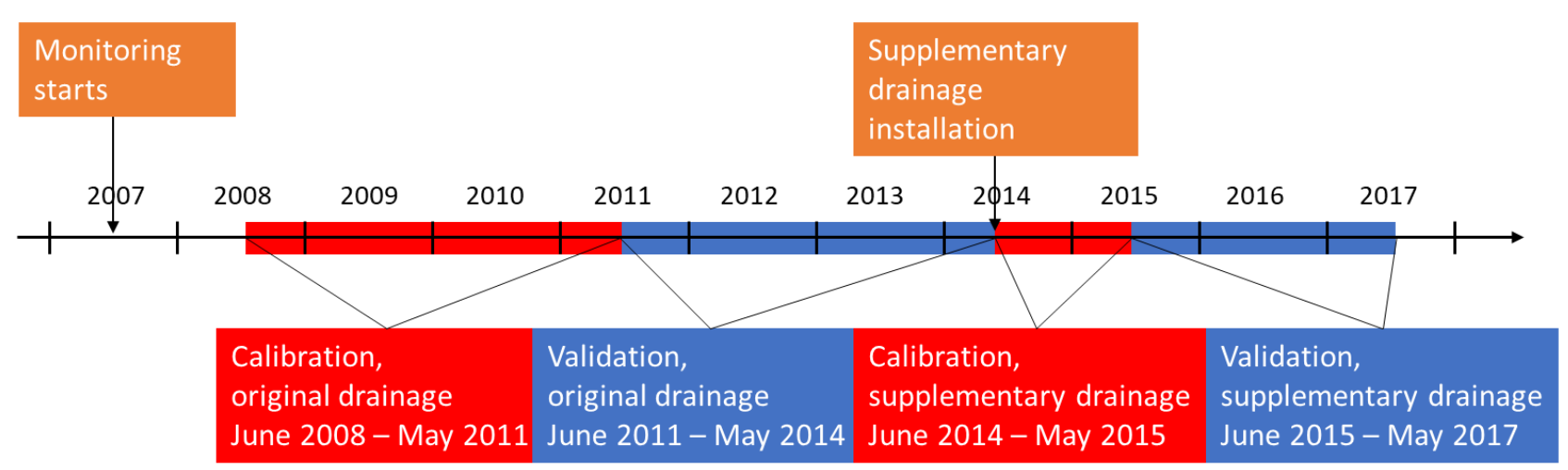

Figure 3. Timeline showing the calibration and validation periods for both drainage setups.

The drain resistance parameters $\lambda$ and $H_{s}$ (Eq. 1) were calibrated to simulate the efficiency of the old tile drain pipes installed in the 1950s. The $\lambda$ and $H_{s}$ parameters for the original drains were calibrated to the values of $7 \mathrm{~m}$ and $0.65 \mathrm{~m}$, respectively. The corresponding values for the supplementary drains were calibrated to $7 \mathrm{~m}$ and $0.15 \mathrm{~m}$. The efficiency of subsurface drains has been found to decrease within the first years (i.e. < 10 years) after installation (e.g. Luoma and Puustinen, 1986; Vakkilainen, 1980). However, the deterioration of the drain efficiency was not considered in this study, as the drain parameters were kept constant throughout the simulation periods in both scenarios. The surface depression storage capacity was calibrated to a value of $0.005 \mathrm{~m}$, which is in line with Turtola et al. (2007) and was kept constant throughout the modeling period. Evapotranspiration was restricted according to Feddes et al. (1978): There was no restriction until a critical soil moisture (-5 m pressure head), after which the restriction increased linearly to the wilting point (-150 m pressure head).

The temperature at the bottom of the computational grid, which works as a boundary condition for the soil heat balance submodel, was set to a constant of $5.9^{\circ} \mathrm{C}$, according to observations by Lemmelä et al. (1981). The snow model in this study was not calibrated; instead, a snow model calibrated and used in previous studies was used (Turunen et al., 2015b). 
Table 1. The main hydrological soil parameters used in the modeling. Parameters are adapted from previous studies according to the table coloring.

\begin{tabular}{|c|c|c|c|c|c|c|c|c|}
\hline Macropores & $\begin{array}{c}\mathbf{K}_{\text {sat }} \\
{\left[\mathbf{m ~ h}^{-1}\right]}\end{array}$ & $\begin{array}{c}\text { Macro- } \\
\text { porosity, } \omega \\
{\left[\mathbf{m}^{3} \mathbf{m}^{-3}\right]}\end{array}$ & $\begin{array}{c}\text { Conductivity } \\
\text { multiplier, } \\
\mathbf{K}_{\text {sat,MULT }} \\
{[-]}\end{array}$ & $\begin{array}{c}\boldsymbol{\theta}_{\text {sat }} \\
{\left[\mathbf{m}^{3} \mathbf{m}^{-3}\right]}\end{array}$ & $\begin{array}{c}\theta_{\mathrm{r}} \\
{\left[\mathrm{m}^{3} \mathbf{m}^{-3}\right]}\end{array}$ & $\begin{array}{c}\alpha \\
{\left[\mathbf{m}^{-1}\right]}\end{array}$ & $\begin{array}{l}\beta \\
{[-]}\end{array}$ & $\mathrm{Kh}_{\text {mult. }}$ \\
\hline \multicolumn{9}{|l|}{ Depth $[\mathrm{m}]$} \\
\hline $0.00-0.20$ & 3.087 & 0.0343 & 90 & 0.56 & 0.01 & 7 & 2 & 0.02 \\
\hline $0.20-0.40$ & 0.09 & 0.001 & 90 & 0.555 & 0.01 & 7 & 2 & 0.83 \\
\hline $0.40-1.00$ & 0.18 & 0.002 & 90 & 0.579 & 0.01 & 7 & 2 & 0.83 \\
\hline $1.00-6.00$ & 0.027 & 0.0003 & 90 & 0.56 & 0.01 & 7 & 2 & 1 \\
\hline \multirow[t]{2}{*}{ Trench (gravel) } & 0.3 & 0.5 & 0.6 & 0.42 & 0.05 & 0.15 & 2.68 & 1 \\
\hline & $\mathbf{K}_{\text {sat }}$ & & & $\theta_{\text {sat }}$ & $\theta_{r}$ & $\alpha$ & $\beta$ & $\mathbf{K h}_{\text {mult. }}$ \\
\hline Soil matrix & {$\left[\mathbf{m ~ h}^{-1}\right]$} & & & {$\left[\mathbf{m}^{3} \mathbf{m}^{-3}\right]$} & {$\left[\mathbf{m}^{3} \mathbf{m}^{-3}\right]$} & {$\left[\mathbf{m}^{-1}\right]$} & {$[-]$} & \\
\hline \multicolumn{9}{|l|}{ Depth [m] } \\
\hline $0.00-0.20$ & 0.0032 & & & 0.56 & 0.1 & 3.561 & 1.147 & 1 \\
\hline $0.20-0.40$ & 0.0001 & & & 0.555 & 0.1 & 0.333 & 1.145 & 1 \\
\hline $0.40-1.00$ & 0.0001 & & & 0.579 & 0.1 & 0.576 & 1.115 & 1 \\
\hline $1.00-6.00$ & 0.0001 & & & 0.56 & 0.1 & 0.576 & 1.115 & 1 \\
\hline Trench (gravel) & 0.3 & & & 0.42 & 0.05 & 0.15 & 2.68 & 1 \\
\hline \multicolumn{3}{|c|}{$\begin{array}{l}\text { = Calculated based on macroporosity and } \\
\text { conductivity multiplier }\end{array}$} & \multicolumn{3}{|c|}{$\begin{array}{l}=\text { Adapted from Warsta et al. (2013a) and } \\
\text { Turunen et al. (2013) }\end{array}$} & \multicolumn{3}{|c|}{ = Adapted from Berisso et al. (2013) } \\
\hline \multicolumn{3}{|c|}{ = Adapted directly from soil analyses } & \multicolumn{3}{|c|}{ = Adapted from Turunen et al. (2013) } & \multicolumn{3}{|c|}{ = Adapted from Haws et al. (2005) } \\
\hline
\end{tabular}

\subsection{Model performance assessment}

Regarding the daily and cumulative drain discharge and topsoil layer runoff, the simulated drain discharge and topsoil layer runoff were assessed with a modified version of the Nash-Sutcliffeefficiency (NSE, Nash and Sutcliffe, 1970), where the squared values were replaced by absolute values (Eq. 2, e.g. Legates and McCabe, 1999). The use of absolute error in the criterion reduces the effect of single larger discharge peak errors and makes the criterion more sensitive to systematic overand underprediction than the use of squared error in the conventional form of the NSE (Krause et al. 2005). 


$$
N S E=1-\frac{\sum_{i=1}^{k}\left|O_{i}-S_{i}\right|}{\sum_{i=1}^{k}\left|O_{i}-O_{\text {mean }}\right|}
$$

where $O_{i}\left[\mathrm{~mm} \mathrm{day}^{-1}\right]$ is the measured daily discharge/runoff, $S_{i}\left[\mathrm{~mm}\right.$ day $\left.^{-1}\right]$ is the simulated discharge/runoff, $O_{\text {mean }}\left[\mathrm{mm} \mathrm{day}^{-1}\right]$ is the mean value of the measured discharge/runoff, and $k$ [-] is the total number of time points (days) of the period studied. Because discharge measurements and simulations contained larger uncertainties during snowy conditions, snowless periods were assessed separately. The snowless periods were formed by selecting only the days when there was no simulated snow pack. NSE values of 0.5 or higher can be considered a satisfactory value (Moriasi et al., 2007). The periodical discharge and runoff quantities were assessed by calculating the relative mass deviation between measured and simulated values for each simulated period.

The capability of the model to simulate the groundwater depth (GWD) in the soil was assessed by comparing the average observed GWD in the locations D1-D5 (see Fig. 1b) to the average simulated GWD in the same locations. The average was used to mitigate any effect of errors in individual observations (Bouma et al., 1980). The goodness-of-fit between observed and simulated GWDs was quantified with the mean absolute error (MAE, e.g. Willmott and Matsuura et al., 2005), which was compared to the mean absolute deviation (MAD) of the observations.

To test the credibility of the simulated scenarios, the bias (Bennett et al., 2012) between the simulated and measured outflows (model bias) as well as the bias between the outflows from the two simulated scenarios (scenario bias) were calculated. 


\section{Results}

\subsection{Model calibration and validation for original drainage}

The values describing model performance from both scenarios are shown in Table 2. The model performance was assessed by calculating the NSE values for both the cumulative (shown in figures 4 and 5) and the daily (shown in Table 2) drain discharge and topsoil layer runoff. The NSE values for the daily drain discharge and topsoil layer runoff were higher (i.e. better model performance), when the periods with active wintertime processes were excluded.

Table 2. The model performance assessment results for the calibration and validation periods for both model scenarios. The simulated daily drain discharge and topsoil layer runoff were assessed with daily NSE and average annual mass deviation. NSE values for snowless periods are shown in parentheses. The simulated GWD was assessed by comparing the mean absolute error between observed and simulated GWDs to the mean absolute deviation of the observations.

\begin{tabular}{|c|c|c|c|c|c|c|c|c|}
\hline $\begin{array}{c}\text { Original } \\
\text { drainage setup }\end{array}$ & Period & $\begin{array}{c}\text { Mass deviation } \\
\text { [\%] } \\
\text { (DD) }\end{array}$ & $\begin{array}{c}\text { Mass deviation } \\
\text { [\%] } \\
\text { (TLR) }\end{array}$ & $\begin{array}{l}\text { NSE [-] } \\
\text { (daily } \\
\text { DD) }\end{array}$ & $\begin{array}{l}\text { NSE [-] } \\
\text { (daily } \\
\text { TLR) }\end{array}$ & $\begin{array}{c}\text { MAE [m] } \\
\text { (GWD) } \\
\text { matrix }\end{array}$ & $\begin{array}{c}\text { MAE }[\mathrm{m}] \\
\text { (GWD) } \\
\text { macro }\end{array}$ & $\begin{array}{l}\text { MAD [m] } \\
\text { (GWD) }\end{array}$ \\
\hline Calibration & June 2008 - May 2011 & -2.2 & -18.4 & $\begin{array}{l}0.38 \\
(0.53)\end{array}$ & $\begin{array}{c}0.49 \\
(0.44)\end{array}$ & 0.52 & 0.91 & 0.18 \\
\hline Validation & June 2011 - May 2014 & 3.5 & -58.3 & $\begin{array}{c}0.39 \\
(0.43)\end{array}$ & $\begin{array}{c}0.53 \\
(0.52)\end{array}$ & 0.31 & 0.78 & 0.09 \\
\hline $\begin{array}{l}\text { Supplementary } \\
\text { drainage setup }\end{array}$ & Period & $\begin{array}{l}\text { Mass deviation } \\
{[\%]} \\
\text { (DD) }\end{array}$ & $\begin{array}{c}\text { Mass deviation } \\
{[\%]} \\
\text { (TLR) }\end{array}$ & $\begin{array}{l}\text { NSE [-] } \\
\text { (daily } \\
\text { DD) }\end{array}$ & $\begin{array}{l}\text { NSE [-] } \\
\text { (daily } \\
\text { TLR) }\end{array}$ & $\begin{array}{c}\text { MAE [m] } \\
\text { (GWD) } \\
\text { matrix }\end{array}$ & $\begin{array}{c}\text { MAE [m] } \\
\text { (GWD) } \\
\text { macro }\end{array}$ & $\begin{array}{c}\text { MAD [m] } \\
\text { (GWD) }\end{array}$ \\
\hline Calibration & June 2014 - May 2015 & -8.8 & -81.3 & $\begin{array}{c}0.42 \\
(0.50)\end{array}$ & $\begin{array}{c}0.47 \\
(0.48)\end{array}$ & 0.39 & 0.97 & 0.16 \\
\hline Validation & June 2015 - May 2017 & -2.6 & -74.3 & $\begin{array}{c}0.25 \\
(0.52)\end{array}$ & $\begin{array}{c}0.48 \\
(0.53)\end{array}$ & 0.58 & 0.96 & 0.09 \\
\hline \multicolumn{9}{|c|}{$\begin{array}{l}\text { DD = Drain discharge } \\
\text { TLR = Topsoil layer runoff } \\
\text { MAE = Mean absolute error } \\
\text { MAD = Mean absolute deviation }\end{array}$} \\
\hline
\end{tabular}

The cumulative outflow in the original drainage scenario (Fig. 4) showed that the model was able to reproduce the measured drain discharge amounts during calibration (3 years) and validation (3 years). The mass deviation was consistently higher for the topsoil layer runoff than the drain discharge (Table 2). 


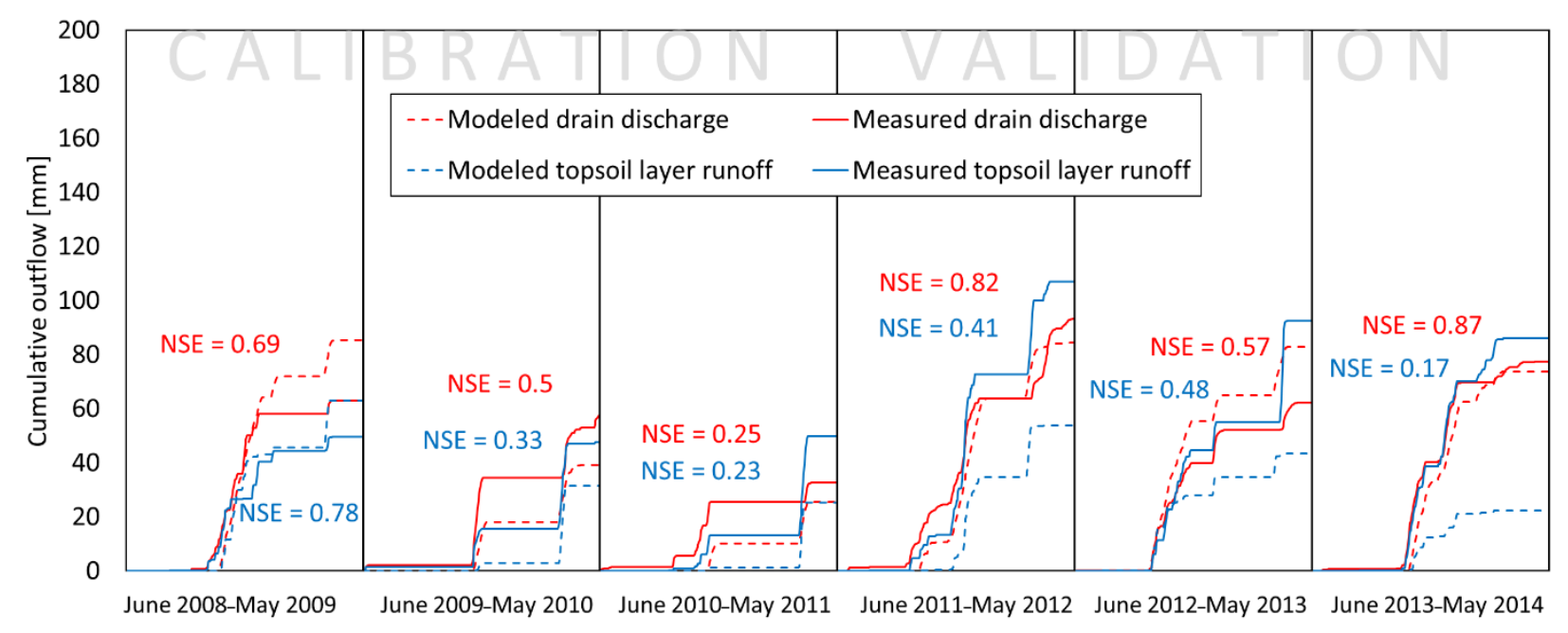

Figure 4. The measured and modeled cumulative outflows from the calibration and validation periods of the original drainage scenario. The NSE values in the graph are computed for the cumulative series.

\subsection{Model calibration and validation for supplementary drainage}

As indicated by the performance criteria (Table 2), the model performed better during the first calibration-validation period (2008-2014) than during the second calibration-validation period (2014-2017), which included the supplementary drains. The model was able to reproduce the measured drain discharge amounts with small absolute differences (15-20 $\mathrm{mm} \mathrm{a}^{-1}$ ) (Fig. 5).

The supplementary drainage simulations showed weaker model performance in terms of topsoil layer runoff than the drain discharge (Table 2), likely due to the small absolute quantity of topsoil layer runoff and its sporadic occurrence. Even though the total mass balance deviations for topsoil layer runoff were high (> 80\% in Table 2), the absolute differences were around 10-30 $\mathrm{mm} \mathrm{a}^{-1}$ (Fig. 5). 


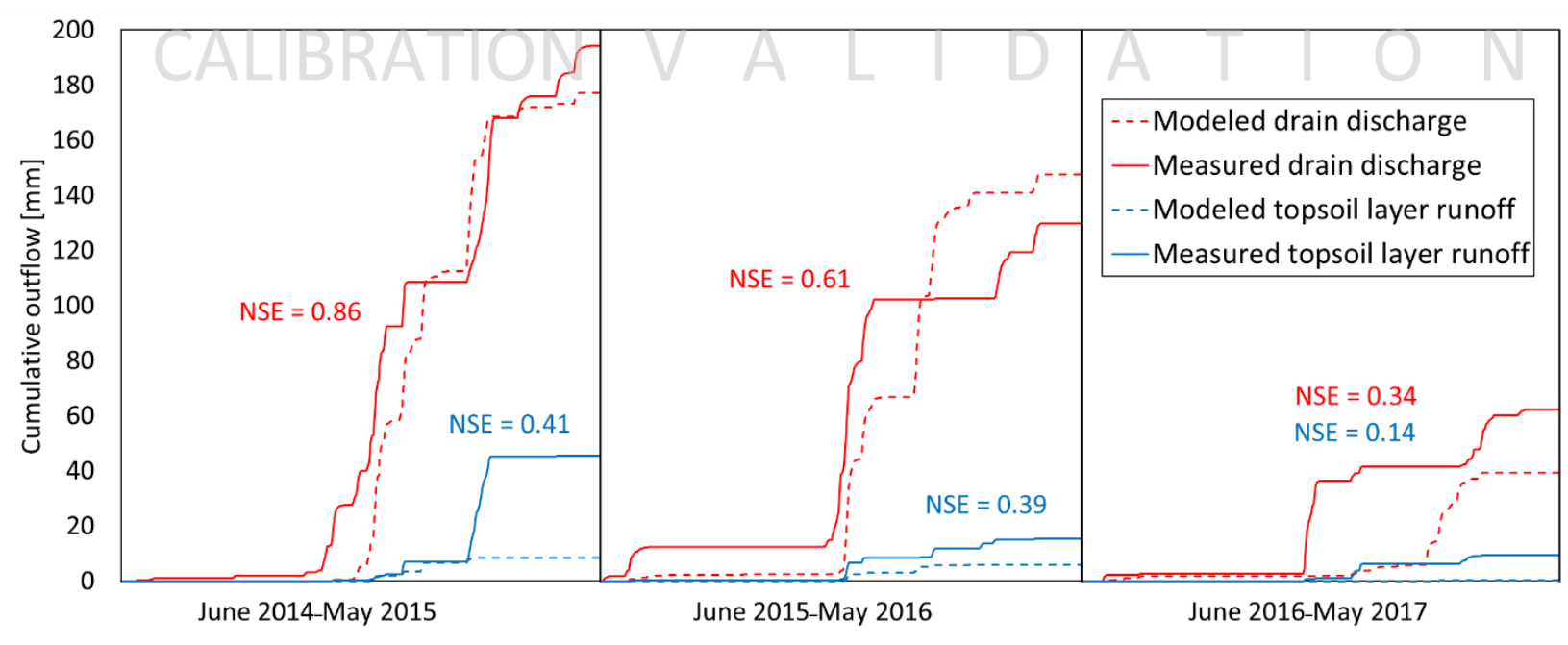

Figure 5. Measured and modeled cumulative outflows from the calibration and validation periods from the supplementary drainage scenario. The NSE values in the graph are computed for the cumulative series.

\subsection{Scenarios}

The simulated drainage setup scenarios (original and supplementary) over the nine-year period of June 2008-May 2017 showed that the supplementary drainage installation clearly increased the drainage discharge, while the topsoil layer runoff and groundwater outflow decreased (Fig. 6). The mean annual drain discharge increased by a factor of 2.6, while the mean annual topsoil layer runoff and groundwater outflow decreased by $75 \%$ and 18\%, respectively. Evapotranspiration was unaffected by the supplementary drainage installation, which reflects the fact that the modeled soil moisture remained above the threshold content and did not restrict evapotranspiration. 

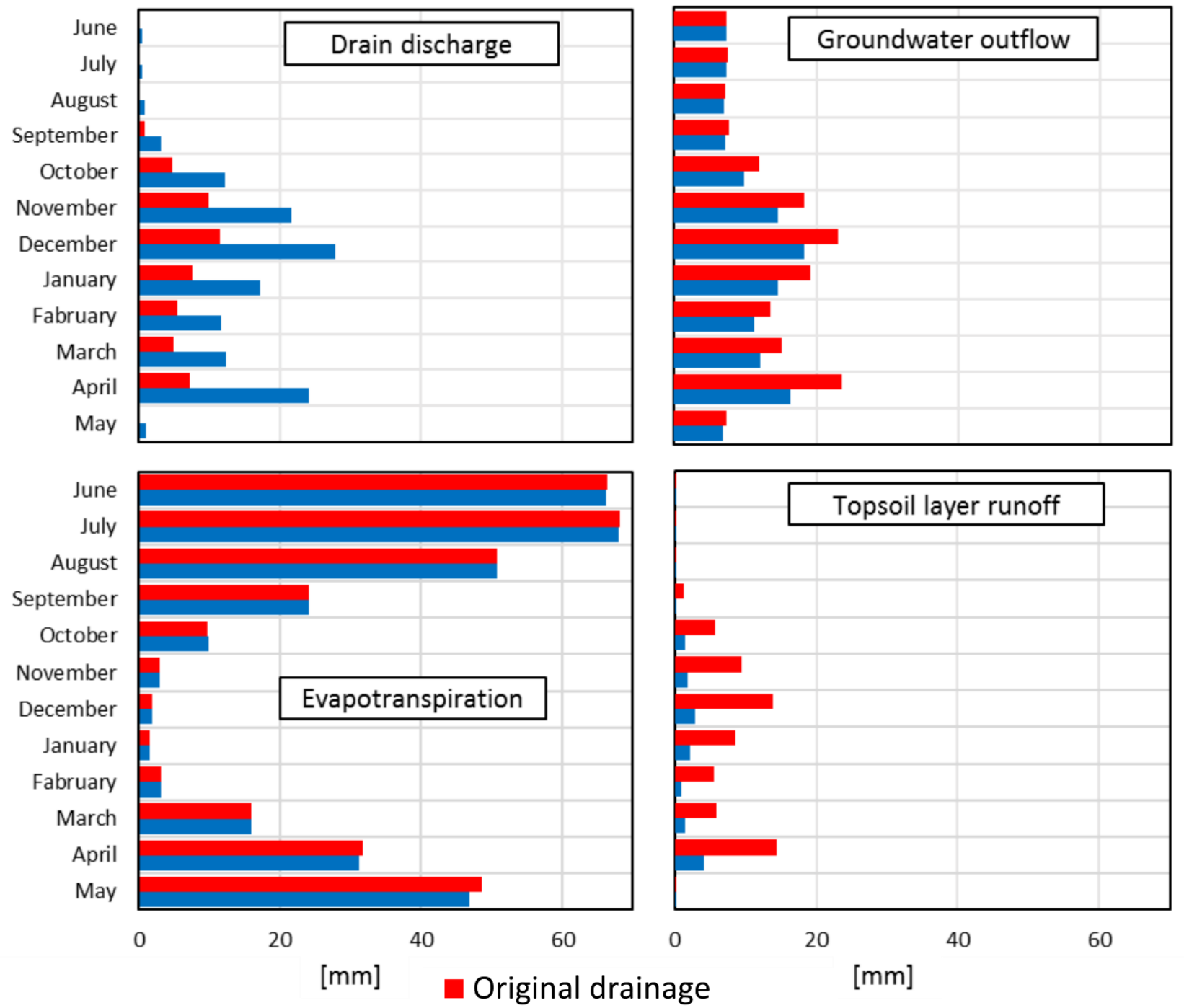

\section{Supplementary drainage}

Figure 6. Simulated monthly average outflow components (drain discharge, topsoil layer runoff and groundwater outflow) and evapotranspiration for original drainage and supplementary drainage scenarios. Average values calculated based on 9 years of data (June 2008-May 2017).

Concerning the drain discharge, the model bias was found to be smaller than the scenario bias in all modeling periods (Table 3). Therefore, the effect of the scenario (original or supplementary) on the simulation results were larger than the model error. Concerning the topsoil layer runoff, however, the model bias was absolutely larger than the scenario bias in one of the modeling periods (Validation 1), which demonstrated that the supplementary drainage impact on the topsoil layer runoff was more challenging to describe compared to the impacts on the drain discharge.

Table 3. The model and scenario biases for both measured outflow components. 


\begin{tabular}{|c|c|c|c|c|}
\hline & \multicolumn{2}{|c|}{ Drain discharge } & \multicolumn{2}{|c|}{ Topsoil layer runoff } \\
\hline & Model & Scenario & Model & Scenario \\
\hline Calibration 1 & -3.08 & -267.40 & -24.70 & 77.59 \\
\hline Validation 1 & 7.38 & -290.35 & -151.84 & 84.07 \\
\hline Calibration 2 & -46.73 & -283.08 & -101.32 & 106.29 \\
\hline Validation2 & -6.77 & -144.41 & -25.04 & 42.65 \\
\hline
\end{tabular}

Cumulative probability of simulated GWD (Fig. 7) showed differences between supplementary and original drainage scenarios during spring (April and May) in terms of drainage efficiency. In the supplementary drainage scenario, $42.5 \%$ of the observations were above $0.6 \mathrm{~m}$ depth, while in the original drainage scenario $56.2 \%$ of the observations were above $0.6 \mathrm{~m}$ depth. In 233 and 308 out of $549(=30 \times 9+31 \times 9)$ days, the groundwater table depth was above $0.6 \mathrm{~m}$ in the supplementary and original drainage scenarios, respectively. These numbers are from the simulation periods of 9 years; and on average, the annual difference between the supplementary and original drainage was 8.4 days $(233 / 9$ - 308/9).

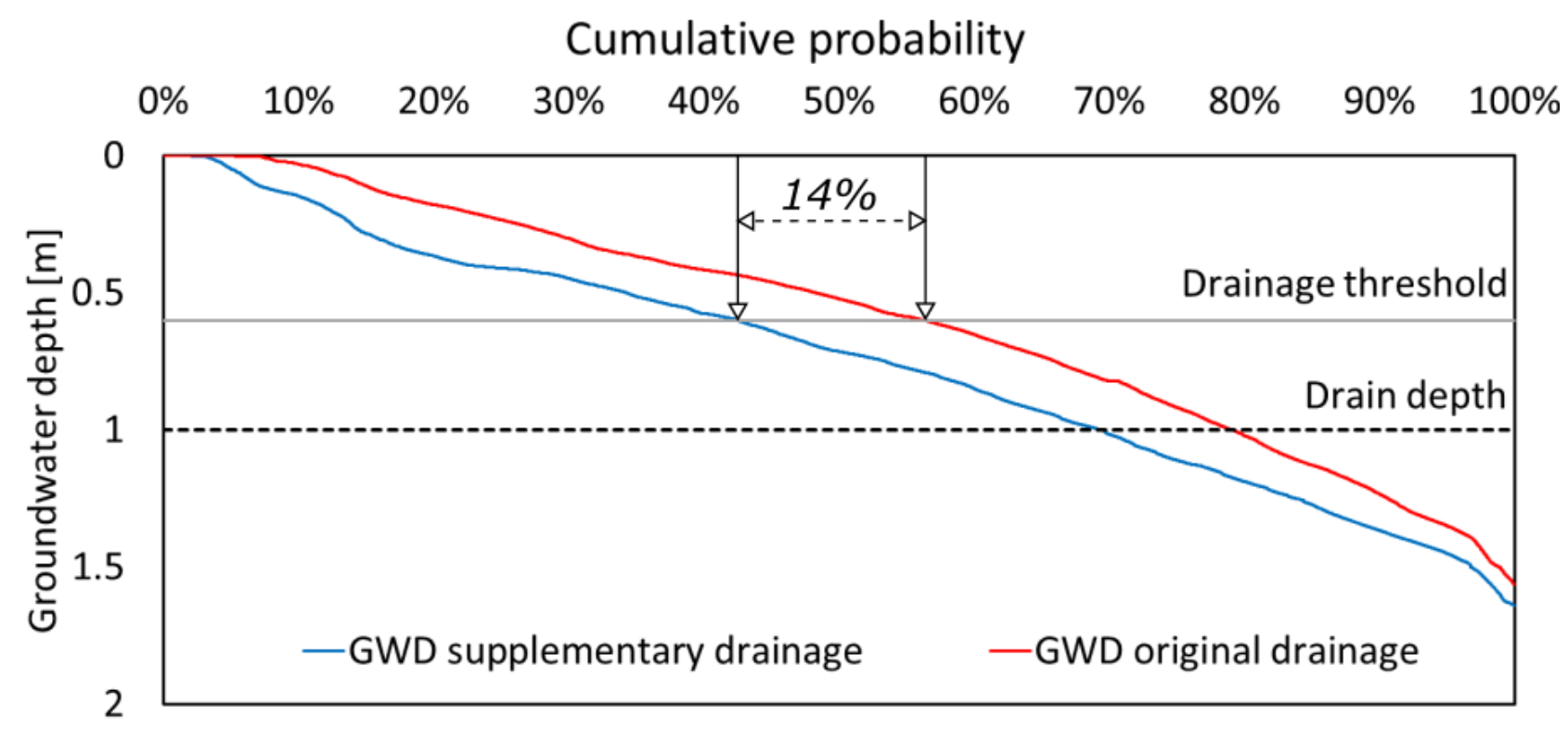

Figure 7. Cumulative probability of simulated groundwater depth during the moths of April and May from the 9-year simulation period for the original $(32 \mathrm{~m})$ and supplementary $(10.7 \mathrm{~m})$ drainage scenarios. The gray horizontal line represents the $0.6 \mathrm{~m} \mathrm{GWD}$ that was used as a reference value for when the field was dry enough to support agricultural machinery without risking soil compaction (i.e. the drainage threshold). 


\section{Discussion}

\subsection{Water balance}

The model provided a quantification of all dominating water balance components and the impacts of supplementary drainage on their shares. In the studied field section prior to the supplementary drainage installation, the amount of drain discharge was low, compared to other subsurface drained field sections in similar climatic conditions: Drain discharge of well-drained fields have been reported to be 40-60\% of the precipitation (Turunen et al. 2015; Uusitalo et al., 2001; Eastman et al., 2010). Outside of the growing season, e.g. during October-April, the share of drain discharge is easily 50$90 \%$ and forms the main water outflow pathway of the field (e.g. Uusitalo et al., 2001). After the supplementary drainage installation, the measured outflow (drain discharge and topsoil layer runoff) corresponded more closely to that of other subsurface drained clayey fields. The simulated drain discharge comprised on average $20.4 \%$ of annual precipitation in the supplementary drainage scenario. The drain discharge was slightly underestimated by FLUSH, as the measured drain discharge was $23 \%$ of annual precipitation.

The hydrological effect of the supplementary drainage installation was clearly visible in the model scenarios (Fig. 6). Also, Turtola and Paajanen (1995), who measured drain discharge and topsoil layer runoff before and after drainage improvements, showed that before the improvements drain discharge comprised $9.8 \%$ and $19.4 \%$ of the total runoff (drain discharge + topsoil layer runoff), depending on cultivation practices; but after the improvements, the corresponding numbers were $83.7 \%$ and $46 \%$. Turtola and Paajanen (1995) reported the shift from topsoil layer runoff to drain discharge outside the growing season (October-April), when most of the discharge and runoff is occurring. However, in this study the increased amount of drain discharge with the supplementary drainage was higher than the amount lost from topsoil layer runoff. Therefore, solely measurements of those two pathways could not reveal the overall effect of improved drainage on all the field water outflow pathways, which has been reported from other field experiments as well (e.g. Seuna and Kauppi, 1981; Bengtson et al., 1988).

Here also the groundwater outflow component was considered; it formed $26 \%$ and $22 \%$ of the water balance in the original drainage scenario and the supplementary drainage scenario, respectively. The groundwater outflow (i.e. lateral subsurface outflow from the field) was triggered by the steep slope in the northeast end of the field section, which seems to function as a natural drainage mechanism. Similar interpretations were done by Turunen et al. (2013). Also, Turunen et al. (2015a) reported that the groundwater outflow comprised $17.9 \%$ of the water balance when applying the FLUSH model on 
a field section in southern Finland that had a 5\% slope. Another strong indication of a prominent groundwater outflow is that the $1.6 \mathrm{~m}$ deep groundwater tubes D1-D5 (in Fig. 1) occasionally emptied completely during winter, even though the drainage depth was 1 m (Äijö et al., 2014), which could not cause the deep GWD. The simulated drainage scenarios showed that supplementary drainage not only decreased the topsoil layer runoff but also the groundwater outflow while increasing the drain discharge (see Section 4.3). In order to study the effects of inter annual variability in the hydrological conditions on supplementary drainage longer simulations periods with corresponding hourly input data would be required. However, the available hourly input data from the Nummela field and the Jokioinen observatory restricted the simulation period to nine years.

\subsection{Model performance}

The topsoil layer runoff proved more challenging to simulate than the drain discharge, even though the NSE values for daily runoff and discharge were in the same order of magnitude (Table 2). The challenge of modeling topsoil layer runoff was due to small runoff quantities $\left(<0.5 \mathrm{~mm} \mathrm{~h}^{-1}\right)$ and dynamic soil surface properties, as Warsta et al. (2013a) reported clearly higher NSE values for the topsoil layer runoff in the case of greater topsoil layer runoff amounts (peaks up to $4 \mathrm{~mm} \mathrm{~h}^{-1}$ ). Warsta et al. (2013) applied the FLUSH model to a clayey agricultural field in southern Finland. Although the NSE values for daily topsoil layer were small and the mass deviation between measured and simulated topsoil layer runoff relatively high (Table 2), in terms of water volume, annual modeled topsoil layer runoff was $62 \mathrm{~mm}$ and $15 \mathrm{~mm}$ (10.3\% and $2.5 \%$ of precipitation) in the original and supplementary drainage scenario, respectively. Therefore, the simulated topsoil layer runoff did not cause a high error in the simulated water balance.

The performance of the model concerning the drain discharge and topsoil layer runoff was better when periods with active wintertime processes were excluded (Table 2). A likely reason for this is that the submodel describing the wintertime processes was not calibrated. Instead, a snow model parametrization applied in a previous study in similar conditions was used (Turunen et al., 2015b). The aim of this study was not to simulate the wintertime processes in detail, but to reproduce the annual water balance of an agricultural field, for which the previously calibrated and validated snow model was seen as adequate. The snow model was only marginally active during the spring periods (April-May) during which the GWD was analyzed (Fig. 7).The annual evapotranspiration constituted on average $56 \%$ of the annual precipitation and was not affected by the drainage scenario (original or supplementary). There are uncertainties in estimating evapotranspiration, and knowledge about the effects of improved drainage on evapotranspiration are not well-documented. Evapotranspiration can 
increase due to more prominent drainage conditions, when crop growth is more likely not harmed by excess soil water (e.g. Rijal et al., 2012). However, this could not be seen from the FLUSH simulations as potential evapotranspiration was only limited in dry root zone conditions (see Section 3.3). According to Feddes et al. (1978), the transpiration may also be restricted by excessively moist conditions (i.e. waterlogging). On the other hand, both Yang et al. (2017) and Khand et al. (2017) reported that evapotranspiration was not significantly different between drained and undrained fields. This study suggested that the effect of supplementary drainage on evapotranspiration during the summer (June-August) was small (Section 4.3, Fig. 6), and the model scenario results showed that GWD was above the drain depth $(1.0 \mathrm{~m}) 20-25 \%$ of the time during the period of June-August. A GWD below drain depth indicated that the drainage system was switched off for most of the summer due to evapotranspiration and groundwater outflow, which were the main water balance components during the growing periods (Fig. 6).

The macroporosity of the deepest soil layer (1.00-6.00 m, Table 1) played an important role in the calibration of the model, as it controlled the division of the total outflow to the three main outflow components (drain discharge, topsoil layer runoff, and groundwater outflow). In this study, two out of three outflow components were measured. The measured variables were considered to constrain the model parameter space enough to conduct a robust estimate of the groundwater outflow amount (e.g. Turunen et al., 2013). Concerning the soil parameters, the aim was to rely on the previous model parametrizations in the Nummela field (Turunen et al., 2013). The groundwater outflow magnitude depended on the soil properties and profile depth beneath the drain depth $(1.0 \mathrm{~m})$ in the simulations. The soil hydraulic properties below the drain depth have been rarely studied. In the current study region, the clay layers above bedrock can reach a depth of $30 \mathrm{~m}$ (GTK, 2018). Also, well-conducting soil layers beneath the drainage depth have been reported by Yli-Halla et al. (2009). Discontinuous macropores can also have a significant contribution to water flow (Nieber and Sidle, 2010), and even the bedrock may not provide an impermeable boundary condition (Tromp-van Meerveld and Weiler, 2008). Detailed soil data on the deeper soil layers was not available, and therefore the number of calibrated parameters was kept to the minimum ( $\omega$ and $\left.\theta_{s a t}\right)$ and the simplified description of the conductivity of the deep soil layers was used. The approach was found to produce a reasonable description of the field hydrology, as assessed against the observations (figures 4 and 5).

\subsection{Groundwater depth in spring}

The field was proven to have problems with excessive moisture before the supplementary drainage installation (Vakkilainen et al., 2010). However, those waterlogging periods mainly occurred during 
spring (prior to cultivation) or autumn after harvest. During the crop growth (May-September), there were on average three weekly measurements that showed groundwater depth above $0.6 \mathrm{~m}$. The main effect on the quantity of crop yield was that cultivation could not start early enough due to high soil moisture long after snow-melt period (e.g. Äijö et al., 2014). This study showed that the supplementary drainage increased the drainage efficiency enough to allow earlier sowing in spring, but did not restrict evapotranspiration (i.e. cause crop drought stress) compared to the original drainage scenario (Fig. 6).

When the practical impacts of the supplementary drainage were assessed in the current study, a groundwater depth of $0.6 \mathrm{~m}$ was used as a threshold value indicating the timing when the field is adequately dry to support agricultural machinery without the risk of soil compaction. A threshold of $0.6 \mathrm{~m}$ is close to the maximum root depth reported by Ilola et al. (1988), entailing the ideal moisture conditions for crops (i.e. no waterlogged roots). There is no clear groundwater depth threshold value defined in the literature for the soil to support heavy agricultural machinery. Mante et al. (2018) reported the link between soil strength and soil water content in the upper soil layers $(0-0.5 \mathrm{~m})$ and used a water content of $87 \%$ of the total pore volume as a threshold value in a sandy loam field. For clay soils, the reported groundwater table depth ranges from $\sim 0.25 \mathrm{~m}$ (Saavalainen, 1983) to $1 \mathrm{~m}$ (Alakukku, 2017). Following the $0.6 \mathrm{~m}$ deep drainage threshold, supplementary drainage can enable field cultivation practices after snowmelt in spring up to 8 days earlier compared to a poorly drained field. Also, the drainage threshold depth did not affect the drainage efficiency difference between the supplementary and original drainage scenarios. The deviation between the cumulative probability curves was nearly constant (Fig. 7).

\section{Conclusions}

Simulations of water balance in a clayey agricultural field section in southern Finland showed that the FLUSH model adequately replicated measured water outflow components over a 10-year period and provided a tool to investigate the hydrological impacts of a supplementary drainage installation. Based on the study results, installation of supplementary drains (decreasing the drain spacing from $32 \mathrm{~m}$ to $10.7 \mathrm{~m}$ ) had three main effects on field hydrology: (1) Supplementary drainage changed the division of water outflow between drain discharge, topsoil layer runoff and groundwater outflow. The mean annual simulated drain discharge increased by a factor of 2.6, while the mean annual simulated topsoil layer runoff, and groundwater outflow decreased by $75 \%$ and $18 \%$, respectively. The decreased topsoil layer runoff could not solely explain the increased drain discharge. The groundwater outflow comprised a considerable part of the water balance and was needed in order to 
close the water balance of the field section. (2) Supplementary drainage installation did not lower the groundwater table during the growing season to the extent that it affected evapotranspiration. More efficient drainage was not found to cause water shortage for the crops. (3) The improved drainage capacity of the supplementary drainage was detectable in the groundwater table depth, as the simulated water table reached a depth of $0.6 \mathrm{~m} 8$ days earlier in spring compared to the original drainage scenario. This indicates that a supplementary drainage installation can be good practice to increase the drainage efficiency in clay soil during spring.

\section{Acknowledgments}

The funding for this research was provided by Drainage Foundation sr and Sven Hallin Research Foundation sr. The authors would like to thank the Finnish Field Drainage Association as well as Aalto University School of Engineering for facilitating the research work. CSC-IT Center for Science, Finland, is acknowledged for the allocation of computational resources. We also wish to thank the two anonymous reviewers for their constructive comments as well as Steve Lipson for the language check.

\section{References}

Äijö, H., Myllys, M., Nurminen, J., Turunen, M., Warsta, L., Paasonen-Kivekäs, M., Korpelainen, E., Salo, H., Sikkilä, M., Alakukku, L., Koivusalo, H., Puustinen, M., 2014. PVO2-hanke: salaojitustekniikat ja pellon vesitalouden optimointi: loppuraportti 2014. [Field drainage methods and optimizing water management of agricultural fields (PVO2) - Final report 2014]. Salaojituksen tutkimusyhdistys ry:n tiedote 31. Helsinki (Finland). Finnish Drainage Research Association; 105.

Äijö, H., Myllys, M., Sikkilä, M., Salo, H., Nurminen, J., Häggblom, O., Turunen, M., PaasonenKivekäs, M., Warsta, L., Koivusalo, H., Alakukku, L., Puustinen, M., 2017. Toimivat salaojitusmenetelmät kasvintuotannossa (TOSKA) - Loppuraportti 2017. [Functioning subdrainage methods in crop production - Final report 2017]. Salaojituksen tutkimusyhdistys ry:n tidote 32. Helsinki (Finland). Finnish Drainage Association; 109.

Alakukku, L., Weisskopf, P., Chamen, W.C.T., Tijink, F.G.J., van der Linden, J.P., Pires, S., Sommer, C., Spoor, G., 2003. Prevention strategies for field traffic-induced subsoil compaction: $a$ review: Part 1. Machine/soil interactions. Soil Tillage Res., Experiences with the Impact and Prevention of Subsoil Compaction in the European Union 73, 145-160. doi:10.1016/S01671987(03)00107-7

Alakukku, L., Nuutinen, V., Ketoja, E., Koivusalo, H., Paasonen-Kivekäs, M., 2010. Soil macroporosity in relation to subsurface drain location on a sloping clay field in humid climatic conditions. Soil Tillage Res. 106, 275-284. doi:10.1016/j.still.2009.11.002

Alakukku, L., 2017. The carrying capacity of agricultural soil depending on groundwater level. Email correspondence with the author. 
Allen, R.G., Pereira, L.S., Raes, D.R., Smith, M., 1998. Crop evapotranspiration: guidelines for computing crop water requirements. FAO Irrigation and drainage paper No. 56 (No. 56). FAO, Rome, Italy.

Aura, E., 1995. Finite element modeling of subsurface drainage in finnish heavy clay soils. Agric. Water Manag. 28, 35-47. doi:10.1016/0378-3774(95)01166-G

Bennett, N.D., Croke, B.F.W., Guariso, G., Guillaume, J.H.A., Hamilton, S.H., Jakeman, A.J., Marsili-Libelli, S., Newham, L.T.H., Norton, J.P., Perrin, C., Pierce, S.A., Robson, B., Seppelt, R., Voinov, A.A., Fath, B.D., Andreassian, V., 2013. Characterising performance of environmental models. Environ. Model. Softw. 40, 1-20. doi:10.1016/j.envsoft.2012.09.011

Berisso, F.E., Schjønning, P., Keller, T., Lamandé, M., Simojoki, A., Iversen, B.V., Allen, L., Forkman, J., 2013. Gas transport and subsoil pore characteristics: Anisotropy and long-term effects of compaction. Geoderma 195-196, 184-191. doi:10.1016/j.geoderma.2012.12.002

Blake, K. R., Hartge, K. H., 1986. Bulk density. In: Klute, A.K. (ed.). Methods of soil analysis. Agronomy 9, Part 1: 363-375. 2. edition.

Bouma, J., Dekker, L.W., Haans, J., 1980. Measurement of depth to water table in a heavy clay soil. Soil Sci. 130, 264-270.

Danielson, R. E., Sutherland, P. I., 1986. Porosity. In: Klute, A.K. (ed.). Methods of soil analysis. Agronomy, Part 1: 443-461. 2. edition.

De Schepper, G., Therrien, R., Refsgaard, J. C., He, X., Kjaergaard, C., and Iversen, B. V., 2017. Simulating seasonal variations of tile drainage discharge in an agricultural catchment. Water Resources Research, 53(5), 3896-3920.

Eastman, M., Gollamudi, A., Stämpfli, N., Madramootoo, C. A., and Sarangi, A., 2010. Comparative evaluation of phosphorus losses from subsurface and naturally drained agricultural fields in the Pike River watershed of Quebec, Canada. Agricultural Water Management, 97(5), 596604.

Elonen, P., 1971. Particle-size analysis of soil. Acta agriculturae Fenniae 122: 1-122.

Feddes, R.A., Kowalik, P.J., Zaradny, H., 1978. Simulation of field water use and crop yield. Wageningen: Pudoc; 189.

Filipović, V., Mallmann, F.J.K.,Coquet, Y., Šimůnek, J., 2014. Numerical simulation of water flow in tile and mole drainage systems. Agric. Water Manage.146: 105-114.

Førland, E.J., Allerup, P., Dahlström, B., Elomaa, E., Jónsson, T., Madsen, H., Perälä, J., Rissanen, P., Vedin, H., Vejen, F., 1996. Manual for operational correction of Nordic precipitation data. Report 24. Oslo: Norwegian Meteorological Institute; 66.

Frey, S.K., Hwang, H.T., Park, Y.J., Hussain, S.I., Gottschall, N., Edwards, M., Lapen, D.R., 2016. Dual permeability modeling of tile drain management influences on hydrologic and nutrient transport characteristics in macroporous soil. J. Hydrol. 535, 392-406. doi:10.1016/j.jhydrol.2016.01.073

Gärdenäs, A.I., Šimůnek, J., Jarvis, N., van Genuchten, M.T., 2006. Two-dimensional modelling of preferential water flow and pesticide transport from a tile-drained field. J. Hydrol. 329, 647660. doi:10.1016/j.jhydrol.2006.03.021

GTK (Geological Survey of Finland), 2018. Maapeitepaksuus 1:1000000. [Soil cover thickness 1:000000] [online] Hakku-portal. [referred to 11.4.2018]. Available at: https://hakku.gtk.fi/fi/locations/search). 
Haahti, K., Warsta, L., Kokkonen, T., Younis, B.A., Koivusalo, H., 2016. Distributed hydrological modeling with channel network flow of a forestry drained peatland site. Water Resour. Res. 52, 246-263. doi:10.1002/2015WR018038

Häggblom, O., 2017. Impacts of improved drainage on the water balance of a poorly drained clayey agricultural field. Master's thesis. Aalto University, School of Engineering, Department of Built Environment. 68 .

Haws, N.W., Rao, P.S., Šimůnek, J. and Poyer, I.C., 2005, Single-porosity and dual-porosity modelling of water flow and solute transport in subsurface-drained fields using effective fieldscale parameters, J. Hydrol, 313, 257-273.

Hintikka, S., Paasonen-Kivekäs, M., Koivusalo, H., Nuutinen, V., Alakukku, L., 2008. Role of macroporosity in runoff generation on a sloping subsurface drained clay field - a case study with MACRO model. Hydrol. Res. 39, 143-155. doi:10.2166/nh.2008.034

Ilola, A., Elomaa, E., Pulli, S., 1988. Testing of a Danish growth model for barley, turniprape and timothy in Finnish conditions. Journal of Agricultural Science in Finland 60, 631-660.

IUSS Working Group WRB, 2015. World Reference Base for Soil Resources 2014, update 2015 International soil classification system for naming soils and creating legends for soil maps, World Soil Resources Reports. No 106. FAO, Rome.

Jarvis, N.J., 2007. A review of non-equilibrium water flow and solute transport in soil macropores: principles, controlling factors and consequences for water quality. Eur. J. Soil Sci. 58, 523546. doi:10.1111/j.1365-2389.2007.00915.x

Jin, C.X., Sands, G.R., 2003. The long-term field-scale hydrology of subsurface drainage systems in a cold climate. Trans. ASAE 46, 1011-1021.

Kandel, H. J., Brodshaug, J. A., Steele, D. D., Ransom, J. K., DeSutter, T. M., Sands, G. R., 2013. Subsurface drainage effects on soil penetration resistance and water table depth on a clay soil in the Red River of the North Valley, USA. Agric Eng Int: CIGR Journal, 15(1):1-10.

Kersalo, J. ed., Pirinen, P. ed., 2009. Suomen maakuntien ilmasto [The Climate of the Regions of Finland]. Finnish Meteorological Institute. Reports 2009:8. ISBN-978-951-697-711-2.

Kessler, T.C., Klint, K.E.S., Nilsson, B., Bjerg, P.L., 2012. Characterization of sand lenses embedded in tills. Quat. Sci. Rev. 53, 55-71. doi:10.1016/j.quascirev.2012.08.011

Khand, K., Kjaersgaard, J., Hay, C., Jia, X., 2017. Estimating Impacts of Agricultural Subsurface Drainage on Evapotranspiration Using the Landsat Imagery-Based METRIC Model. Hydrology. 4. 10.3390/hydrology4040049.

Klaus, J., Zehe, E., 2010. Modelling rapid flow response of a tile-drained field site using a 2D physically based model: assessment of 'equifinal' model setups. Hydrol. Process. 24(12), 1595-1609. DOI: 10.1002/hyp.7687

Koivusalo, H., Karvonen, T., Paasonen-Kivekäs, M., 1999. Application of a two-dimensional model to calculate water balance of an agricultural hillslope. Phys. Chem. Earth Part B Hydrol. Oceans Atmosphere 24, 313-318. doi:10.1016/S1464-1909(99)00006-4

Koivusalo, H., Heikinheimo, M., Karvonen, T., 2001. Test of a simple two-layer parameterisation to simulate the energy balance and temperature of a snow pack. Theor. Appl. Climatol. 70, 6579. doi:10.1007/s007040170006

Koivusalo, H., Turunen, M., Salo, H., Haahti, K., Nousiainen, R., Warsta, L., 2017. Analysis of water balance and runoff generation in high latitude agricultural fields during mild and cold winters. Hydrology Research, Vol. 48, No. 4, 08.2017, 957-968. DOI: 10.2166/nh.2017.056. 
Krause, P., Boyle, D. P., Bäse, F., 2005. Comparison of different efficiency criteria for hydrological model assessment. Advances in Geosciences, European Geosciences Union, 5, 89-97.

Legates, D. R. and McCabe Jr., G. J., 1999. Evaluating the use of "goodness-of-fit" measures in hydrologic and hydroclimatic model validation. Water Resour. Res., 35, 1, 233-241

Lemmelä, R., Sucksdorff, Y., Gilman, K., 1981. Annual variation of soil temperature at depth 20 to $700 \mathrm{~cm}$ in an experimental field in Hyrylä, South-Finland during 1969 to 1973. Geophysica 17, 143-154.

Luke (Natural Resources Institute Finland), 2018. Maannostiedot. [online] Taloustohtori portal. [referred to 26.7.2018]. Available at: https://portal.mtt.fi/portal/page/portal/taloustohtori/maannostieto/vakioraportit/maalajitiedot _wrb_luokitus/maalajit_maakunnittain

Luoma, T., Puustinen, M., 1986. The reasons behind inadequate drainage and some methods of solving them. In: Saavalainen, J., Vakkilainen, P., (Eds.), Proceedings of International Seminar on Land Drainage, July 9-11, 1986, Helsinki, Finland, 267-274.

Mante, A. A., Ramanathan, S. R., Bullock, P., 2018. Subsurface drainage for promoting soil strength for field operations in southern Manitoba. Soil and Tillage Research, Vol. 18, 261-264.

McKnight, U. S., Rasmussen, J. J., Kronvang, B., Binning, P. J., and Bjerg, P. L., 2015. Sources, occurrence and predicted aquatic impact of legacy and contemporary pesticides in streams. Environmental Pollution, 200, 64-76. DOI: 10.1016/j.envpol.2015.02.015

Messing, I. and Wesström, I., 2006. Efficiency of old tile drain systems in soils with high clay content: Differences in the trench backfill zone versus the zone midway between trenches. Irrigation and drainage, 55(5), 523-531.

Moriasi, D. N., Arnold, J. G., van Liew, M. W., Bingner, R. L., Harmel, R. D., Veith, T. L., 2007. Model Evaluation Guidelines for Systematic Quantification of Accuracy in Watershed Simulations. Transactions of the ASABE. American Society of Agricultural and Biological Engineers ISSN 0001-2351. Vol. 50(3): 885-900.

Nash, J.E., Sutcliffe, J.V., 1970. River flow forecasting through conceptual models part I-A discussion of principles. J. Hydrol. 10, 282-290.

Nieber, J. L., Sidle, R. C., 2010. How do disconnected macropores in sloping soils facilitate preferential flow? Hydrol. Process. 24, 1582-1594 (2010). Published online 29 March 2010 in Wiley InterScience (www.interscience.wiley.com) DOI: 10.1002/hyp.7633

Nollet, L. M., and Rathore, H. S. (red:er)., 2012. Pesticides: evaluation of environmental pollution. Boca Raton: CRC press.

Peltomaa, R., 2016. Salaojitus [Subsurface drainage]. In: Paasonen-Kivekäs, M., Peltomaa, R., Vakkilainen, P., Äijö, H. (Eds.), Maan vesi- ja ravinnetalous - Ojitus, kastelu ja ympäristö [The water and nutrient economy of the soil - Drainage, irrigation and environment], 2nd edition. Salaojayhdistys ry, Helsinki. 283-336.

Puustinen, M., Merilä, E., Palko, J., Seuna, P., 1994. Kuivatustila, viljelykäytäntö ja vesistökuormitukseen vaikuttavat ominaisuudet Suomen pelloilla. In: With an English abstract: [Drainage Level, Cultivation Practices and Factors Affecting Load on Waterways in Finnish Farmland]. Vesi- ja ympäristöhallinnon julkaisuja - sarja A 198. National Board of Waters and Environment, Helsinki, Finland, 319.

Richards, L.A., 1931. Capillary conduction of liquids through porous mediums. Physics 1, 318-333. 
Rijal, I., Jia, X., Zhang, X. F., Steele, D. D., Scherer, T., Akyuz, A., 2012. Effects of Subsurface Drainage on Evapotranspiration for Corn and Soybean Crops in Southeastern North Dakota. Journal of Irrigation and Drainage Engineering 138(12): 1060-1067. DOI: 10.1061/(ASCE)IR.1943-4774.0000508

Rozemeijer, J.C., Broers, H.P., 2007. The groundwater contribution to surface water contamination in a region with intensive agricultural land use (Noord-Brabant, The Netherlands). Environ. Pollut., AquaTerra: Pollutant behavior in the soil, sediment, ground, and surface water system 148, 695-706. doi:10.1016/j.envpol.2007.01.028

Rozemeijer, J.C., van der Velde, Y., van Geer, F.C., Bierkens, M.F.P., Broers, H.P., 2010. Direct measurements of the tile drain and groundwater flow route contributions to surface water contamination: From field-scale concentration patterns in groundwater to catchment-scale surface water quality. Environ. Pollut. 158, 3571-3579. doi:10.1016/j.envpol.2010.08.014

Ruosteenoja, K., Jylhä, K., Kämäräinen, M., 2016. Climate Projections for Finland under the RCP Forcing Scenarios. Geophysica, 51.

Saavalainen, J., 1983. Salaojittajan käsikirja, osa I B [Handbook of drainage designer, part I B]. Helsinki, Salaojakoulutuksen kannatusyhdistys. 83.

Saavalainen, J., 2001. Saatesanat. In: Salaojitus Suomessa 1950-2000. Salaojituksen perinneyhdistys, 8-9.

Salaojayhdistys, 2015. Peltosalaojitus [Subsurface drainage]. Salaojayhdistys ry. 28.

Salo, H., Warsta, L., Turunen, M., Paasonen-Kivekäs, M., Nurminen, J., Koivusalo, H., 2015. Development and application of a solute transport model to describe field-scale nitrogen processes during autumn rains, Acta Agriculturae Scandinavica, Section B - Soil \& Plant Science, 65:sup1, 30-43, DOI: 10.1080/09064710.2014.971861

Salo, H., Warsta, L., Turunen, M., Nurminen, J., Myllys, M., Paasonen-Kivekäs, M., Alakukku, L., Koivusalo, H., 2017. Simulating 3-D water flow in subsurface drain trenches and surrounding soils in a clayey field. Soil and Tillage Research, Volume 168, 20-32. https://doi.org/10.1016/j.still.2016.12.002.

Seuna, P., Kauppi, L., 1981. Influence of sub-drainage on water quantity and quality in a cultivated area in Finland. Publications of the Water Research Institute 43, 32-47.

Šimůnek, J. and van Genuchten, M.T., 2008. Modeling nonequilibrium flow and transport processes using HYDRUS, Vadose Zone J. 2008 7: 782-797.

Tike, Maa- ja Metsätalousministeriön tietopalvelukeskus, 2014. Maatilatilastollinen vuosikirja 2014 [Yearbook of Farm Statistics 2014s]. Tike, Maa- ja metsätalousministeriön tietopalvelukeskus. 327.

Tromp-van Meerveld, I., Weiler, M., 2008. Hillslope dynamics modeled with increasing complexity. Journal of Hydrology 361, 24-40.

Turtola, E., Paajanen, A., 1995. Influence of improved subsurface drainage on phosphorus losses and nitrogen leaching from a heavy clay soil. Agric. Water Manag. 28, 295-310. doi:10.1016/0378-3774(95)01180-3

Turtola, E., Alakukku, L., Uusitalo, R., 2007. Surface runoff, subsurface drainflow and soil erosion as affected by tillage in a clayey Finnish soil. Agricultural and Food Science 16, 332-351.

Turunen, M., Warsta, L., Paasonen-Kivekäs, M., Nurminen, J., Myllys, M., Alakukku, L., Äijö, H., Puustinen, M., Koivusalo, H., 2013. Modeling water balance and effects of different 
subsurface drainage methods on water outflow components in a clayey agricultural field in boreal conditions. Agric. Water Manag. 121, 135-148. doi:10.1016/j.agwat.2013.01.012

Turunen, M., Warsta, L., Paasonen-Kivekäs, M., Nurminen, J., Alakukku, L., Myllys, M., Koivusalo, H., 2015a. Effects of terrain slope on long-term and seasonal water balances in clayey, subsurface drained agricultural fields in high latitude conditions. Agric. Water Manag. 150, 139-151. doi:10.1016/j.agwat.2014.12.008

Turunen, M., Warsta, L., Paasonen-Kivekäs, M., Nurminen, J., Koivusalo, H., 2015b. Simulating water balance and evapotranspiration in a subsurface drained clayey agricultural field in high-latitude conditions. Acta Agric. Scand. Sect. B - Soil Plant Sci. 65, 44-57. doi:10.1080/09064710.2014.975834

Uusitalo, R., Turtola, E., Kauppila, T., and Lilja, T., 2001. Particulate phosphorus and sediment in surface runoff and drainflow from clayey soils. Journal of Environmental Quality, 30(2), 589595.

Warsta, L., Turunen, M., Koivusalo, H., Paasonen-Kivekäs, M., Karvonen, T., Taskinen, A., 2012. Modelling heat transport and freezing and thawing processes in a clayey, subsurface drained agricultural field, in: 11th ICID Int. Drainage Workshop on Agricultural Drainage Needs and Future Priorities. Cairo. 23-27.

Warsta, L., Karvonen, T., Koivusalo, H., Paasonen-Kivekäs, M., Taskinen, A., 2013a. Simulation of water balance in a clayey, subsurface drained agricultural field with three-dimensional FLUSH model. J. Hydrol. 476, 395-409. doi:10.1016/j.jhydrol.2012.10.053

Warsta, L., Taskinen, A., Koivusalo, H., Paasonen-Kivekäs, M., Karvonen, T., 2013b. Modelling soil erosion in a clayey, subsurface-drained agricultural field with a three-dimensional FLUSH model. J. Hydrol. 498, 132-143. doi:10.1016/j.jhydrol.2013.06.020

Vakkilainen, P., 1980. Tutkimus pellon tiivistymisen vaikutuksesta salaojien toimintaan [A study on how the compaction of the soil affects the performance of subsurface drains]. Vesitalous 2 , $23-28$.

Vakkilainen, P., Alakukku, L., Koskiaho, J., Myllys, M., Nurminen, J., Paasonen-Kivekäs, M., Peltomaa, R., Puustinen, M., Äijö, H., 2010. Pellon vesitalouden optimointi - Loppuraportti 2010. Salaojituksen tutkimusyhdistys ry:n tiedote 30. Finnish Field Drainage Association, Helsinki, Finland, 114.

van Genuchten, M.Th., 1980. A closed-form equation for predicting the hydraulic conductivity of unsaturated soils. Soil Science Society of America Journal 44, 892-898.

Weiler, M., McDonnell, J.J., 2007. Conceptualizing lateral preferential flow and flow networks and simulating the effects on gauged and ungauged hillslopes. Water Resour. Res. 43, W03403. doi:10.1029/2006WR004867

Williams, J., Shaykewich, C.F., 1969. An Evaluation of Polyethylene Glycol (p.e.g.) 6000 and P.e.g. 20,000 in the Osmotic Control of Soil Water Matric Potential. Can. J. Soil Sci. 49, 397-401. doi:10.4141/cjss69-054

Willmott, C. J., Matsuura, K., 2005. Advantages of the mean absolute error (MAE) over the root mean aquare error (RMSE) in assessing average model performance. Climate Research Vil. 30:79-82.

Yli-Halla, M., Mokma, D.L., Alakukku, L., 2009. Evidence for the formation of Luvisols/Alfisols as a response to coupled pedogenic and anthropogenic influences in a claysoil in Finland. AgrFoodSciFinland.18:388-401. 
Yang, Y., Anderson, M., Gao, F., Hain, C., Kustas, W., Meyers, T., ... \& Yang, Y. (2017). Impact of tile drainage on evapotranspiration in South Dakota, USA, based on high spatiotemporal resolution evapotranspiration time series from a multisatellite data fusion system. IEEE Journal of Selected Topics in Applied Earth Observations and Remote Sensing, 10(6), 25502564.

Youngs, E.G., 1991. Hydraulic conductivity of saturated soils, in: Smith, K.A., Mullins, C.E. (Eds.), Soil Analysis. Physical Methods. 620. 